\title{
LEGITIMIDADE DA JUSTIÇA CONSTITUCIONAL
}

\author{
Alexandre de Moraes \\ Professor Associado da Faculdade de Direito da \\ Universidade de São Paulo. Secretário de Estado da \\ Justiça e Cidadania de São Paulo
}

\begin{abstract}
Resumo:
A Democracia representativa pelos Parlamentos e pelo Estado de Direito. A questão da legitimidade da Justiça Constitucional, somada à composição dos tribunais constitucionais são as metas principais desenvolvidas neste trabalho.
\end{abstract}

Abstract:

The representative Democracy by the Parliaments and the Rule of Law. The Constitutional Justice and its legitimity question, added to the composition of the constitutional courts are the aims developed in this work.

Unitermos: Democracia; Estado de Direito; Tribunais Constitucionais; Poder Constituinte.

1. Introdução.

A lei enquanto obra do legislador e expressão da vontade soberana do povo, que consiste em tradição do século XIX, tornou-se mera ficção, ${ }^{1}$ pois seja em virtude da flagrante crise da Democracia representativa, seja pelo fortalecimento do poder político dos grupos de pressão, a lei não necessariamente representa o povo e, por muitas vezes, desrespeita princípios e direitos fundamentais básicos, com a finalidade de favorecimento de alguns poucos, mas poderosos, grupos de pressão.

Nesse sentido, importante a observação feita por Rivero, de que " $a$ idéia de representação da vontade do cidadão pelo eleito, tem progressivamente diminuído na realidade, mediante a tomada de consciência pelo eleitor de que, definitivamente, os homens que são eleitos atuam para si mesmos e não para eles. $O$

1. Como salienta Cappelletti, "é um fato que nas sociedades pluralistas os Parlamentos se compõem fundamentalmente de políticos localmente eleitos e de políicos eleitoralmente vinculados a determinadas categorias ou certos grupos. Os valores e prioridades desses políticos, pelos quais estão mais do que dispostos a gastar o dinheiro público, não são com freqüência mais que valores e prioridades locais ou de grupos" (CAPPELLETTI, Mauro. Necesidad y legitimidad de la justicia constitucional. In: Vários autores. Tribunales constitucionales europeus y derechos fundamentales. Madri: Centro de Estudios Constitucionales, 1984. p. 606). 
cidadão, ante essa avalancha de leis, cada vez mais completas, cada vez mais técnicas, cada vez mais conformadas com a vontade governamental, não reconhece sua própria vontade", para concluir que "essa transformação da lei conduz à tomada de consciência da necessidade de proteger os direitos fundamentais, inclusive perante a própria lei" ${ }^{2}$

Dentro dessa perspectiva, acentua-se a necessidade de conjugarem-se e compatibilizarem-se as idéias de Democracia, que se manifesta basicamente pela forma representativa, por meio dos Parlamentos, e de Estado de Direito, que se manifesta pela consagração da supremacia constitucional e o respeito aos direitos fundamentais, tornando-se, portanto, clara a legitimidade da Justiça constitucional e a necessidade de existência de seus órgãos, dotados de plena independência e que possam instrumentalizar a proteção dos preceitos e direitos constitucionais fundamentais. ${ }^{3}$

Essa necessidade foi apontada por René David, ao analisar o Direito Comparado, afirmando que "existe uma tendência nítida, atualmente, de reforçar o valor das normas constitucionais, elevando-as, na prática, acima das leis ordinárias. A Constituição da República Federal da Alemanha declara: 'O poder legislativo deve respeitar as leis e o direito. Todo alemão tem direito de resistir, se nenhum outro meio pode ser usado, contra quem quer que seja que tente destruir este ordenamento Procurou-se encontrar meios de garantir a ordem constitucional em numerosos países e, em particular à semelhança dos Estados Unidos, se admitiu um controle judiciário da constitucionalidade das leis. As evoluções mais características se produziram na Alemanha Federal e na Itália, como reação contra os regimes que nestes países haviam escarnecido dos princípios da Democracia e dos direitos humanos; uma abundante jurisprudência, nestes países, declarou nulas as leis que atentavam contra os direitos fundamentais (Grundrechte, Diritti Fundamentali), enumerados em uma declaração de direitos incorporada à Constituição" "

No exercício dessa grave missão de garantidora do Estado de Direito5 e

2 RIVERO, Jean. A modo de sintesis. In: Vários autores. Tribunales constitucionales europeus y derechos fundamentales. Madri: Centro de Estudios Constitucionales, 1984. p. 667.

3. Cf. REYES, Manuel Aragón. El juez ordinario entre legalidade y constituciomalidad. Bogotá: Instituto de Estudios Constitucionales, 1997. pp. 16-19.

4. DAVID, René. Os grandes sistemas do direito comtemporâneo. São Paulo: Martins Fontes, 1998. p. 54.

5. No sentido que Ihe é dado por Konrad Hesse: "O estado de direito, é na estrutura constitucional da Lei Fundamental, finalmente, forma de limitação do poder estatal. Ele produz essa não pela exclusão de uma "esfera livre do Estado e do direito" do particular; porque essa esfera seria incapaz de ganhar realidade e de garantir um estado de liberdade real, que somente é importante para a Lei Fundamental. Senão, ele afiança liberdade por uma ordem total liberal que, por um lado, organiza vinculativamente $e$ 
dos direitos fundamentais, a Justiça constitucional em suas várias organizações possui, geralmente, cinco grandes ramos de competência: ${ }^{\natural}$ a. controle da constitucionalidade das leis c atos normativos do poder público; b. proteção aos dircitos fundamentais; $c$. controle das regras da Democracia representativa (eleições) e participativa (referendos e plebiscitos); d. controle do bom funcionamento dos poderes públicos e da regularidade no exercício de suas competências constitucionais; e. equilíbrio da federação.

A questão da legitimidade da Justiça constitucional em confronto com a legitimidade da maioria legislativa coloca-se de forma acentuada no campo do controle concentrado de constitucionalidade, uma vez que se concede a um Corpo de Magistrados poderes para declaração de inconstitucionalidade de uma lei ou ato normativo, afetando a produção legiferante do Parlamento, ${ }^{7}$ enquanto representante direto das aspirações populares em uma Democracia representativa. ${ }^{x}$

Assim, questiona-se a legitimação democrática do fundamento da jurisdição constitucional, colocando-a em confronto com o Princípio Democrático representativo."

Como lembra José de Sousa e Britto, "o problema do fundamento da jurisdição constitucional é tão-somente o problema da sua legitimação democrática.

em uma forma coordena mutuamente os âmbitos da atividade estatal, exclui, no possível, o abuso do poder, por outro, assenta sobre um status liberal do particular juridicamente garantido, organizado $e$ protegido" (HESSE, Konrad. Elementos de direito constitucional da República Federal da Alemanha. Porto Alegre: Sérgio Fabris, 1998. p. 161).

6. Cf. a respeito: FAVOREU, Louis. Informe general introductorio. In: Vários autores. Tribunales Constitucionales europeus y derechos findamentales. Madri: Centro de Estudios Constitucionales, 1984. p. 22; CANOTILHO, J. J. Gomes. Direito constitucional e teoria da Constituiçăo. 2. ed. Coimbra: Alınedina, 1998. p. 789.

7. Nuno Piçarra analisa essa problemática eın item denominado "Balança entre função legislativa e função jurisdicional?" (PIÇARRA, Nuno. A separação dos poderes como doutrina e princípio constitucional. Coimbra: Coimbra, 1989. p. 258), Conferir, ainda: QUEIROZ, Cristina M. M. Os actos políticos no estado de direito. Coimbra: Almedina, 1990, p. 164.

8. Essa idéia é corroborada por Vieira de Andrade, que expõe ser "no campo da fiscalizaşão sucessiva abstracta que se opõem frontalmente a legitimidade da justiça constitucional e a legitimidade da maioria legislativa, tendo em consideração, designadamente, os poderes do Tribunal Constitucional de declaraçăo com força obrigatória geral da inconstitucionalidade da norma on mesmo só de um segmento ideal dessa mesma norma" (ANDRADE, J. C. Vieira de. Legitimidade da justiça constitucional e princípio da maioria. In: Vários autores. Legitimidade e legitimaçăo da justiça constitucional. Coimbra: Coimbra, 1995. p. 76). Cf, ainda: STARCK, Christian. La légitimité de la justice constitutionnelle et le principe democratique de majorite. In: Vários autores. Legitimidade e legitimaşăo da justiça constitucional. Coimbra: Coimbra, 1995. p. 60.

9. Cf. CANOTILHO, J. J. Gomes. Jurisdição constitucional e intranquilidade discursiva. Perspectivis.s constitucionais nos 20 anos da Constituição de 1976. Coimbra: Coimbra, 1996. v.1. p. 87J, ss. 
Não é verdade que, pelo próprio facto da sua existência, há juízes que declaram inválida uma lei, a expressão da vontade do povo? A questão pressupõe, portanto, habitualmente, que o poder legislativo do povo, através dos seus representantes eleitos, é a dimensão essencial da Democracia e que a jurisdição constitucional é uma restrição à Democracia na medida em que retira, pelo menos em parte, à lei a sua força. Por que razão deveriam os juízes, que não são legisladores eleitos pelo povo, poder afectar a força duma lei democrática? Não é isto governo dos juízes em vez de governo do povo? A teoria tradicional vê, portanto, na jurisdição constitucional um limite ou uma restrição ao princípio do governo do povo pelo povo. A questão será, portanto, a de justificar essa restrição" 10

Importante estabelecer nesse estudo os três sustentáculos básicos da legitimidade da Justiça constitucional, a partir dos quais será possível identificar a plena compatibilidade entre o governo da maioria e o controle jurisdicional de constitucionalidade: complementaridade entre Democracia e Estado de Direito; composição dos Tribunais Constitucionais e fundamentação e aceitação popular das decisões dos Tribunais Constitucionais.

2. Complementaridade entre Democracia e Estado de Direito.

A premissa básica que justifica a legitimidade da Justiça constitucional parte da idéia de complementaridade entre Democracia e Estado de Direito, pois enquanto a Democracia consubstancia-se no governo da maioria, baseado na soberania popular, o Estado de direito consagra a supremacia das normas constitucionais, o respeito aos direitos fundamentais e o controle jurisdicional do Poder Estatal, não-só para proteção da maioria, mas também, e basicamente, dos direitos da minoria."

Importante recordarmos a advertência feita por Walter Berns, ao comentar os princípios fundadores da Constituição norte-americana, em relação à maioria: " $E m$ resumo, a regra da maioria só pode ser justificada se os homens são iguais e eles só são iguais na posse de direitos. Uma política de igualdade, portanto, precisa ser uma

10. BRITO, José de Sousa. Jurisdição constitucional e princípio democrático. In: Vários autores. Legitimidade e legitimação da justiça constitucional. Coimbra: Coimbra, 1995. p. 39.

11. Como salientado por Lawrence Baum, "a Corte Suprema é política numa variedade de sentidos... As percepções que os juizes têm da opinião pública e da opinião do Comgresso afetan as decisões da Corte. As próprias decisöes, com freqüência, levam grandes controvérsias no Governo e na Nação em geral, e os juizes podem ser atacados por membros do Congresso e por outros líderes politicos que discordam de suas políticas" (A Suprema Corte Americama. Rio de Janeiro: Forense Universitária, 1987, pp. 12-13). 
política preocupada com direitos. Conseqüentemente, a regra da maioria, só é legitima se na prática a maioria respeita os direitos da minoria" 12

Assim, é absolutamente necessária a compatibilização do Parlamento (que representa o princípio democrático da maioria) com a Justiça constitucional (que representa a garantia do Estado de Direito) ${ }^{13}$ e a defesa dos direitos da minoria. ${ }^{14}$

Observe-se que a jurisdição constitucional retira sua legitimidade formalmente da própria Constituição e materialmente da necessidade de proteção ao Estado de Direito e aos Direitos Fundamentais, pois como recorda Jorge Miranda, "o irrestrito domínio da maioria poderia vulnerar o conteúdo essencial daqueles direitos, tal como o princípio da liberdade poderia recusar qualquer decisão política sobre a sua modulação" 15

Formalmente, as decisões dos Tribunais Constitucionais prevalecem sobre a dos representantes populares eleitos pelo voto, porque presume-se que o povo assim desejou na elaboração da Constituição, por meio do exercício de poder constituinte originário.

Ora, enquanto manifestação soberana da suprema vontade política de um povo, social e juridicamente organizado, o poder constituinte originário, modernamente tem o povo como seu titular, ${ }^{16}$ cuja vontade é expressa por meio de

12. BERNS, Walter. A Constituição assegura esses direitos? In: Vários autores. A Constituição norteamericana. Rio de Janeiro: Forense Universitária, 1986. p. 285. A necessidade de garantirem-se os direitos da minoria, também é ressaltada por Joseph Bessette, que aponta que "a versão mais comum da acusaçāo de que o sistema político norte-americano é atualmente antidemocrático talvez seja a de que os poucoss endinheirados, especialmente os interesses empresariais, subvertem as formas da Democracia para seus próprios fins estreitos" (BESSETTE, Joseph M. Democracia deliberativa: o princípio da maioria no governo republicano. In: Vários autores. A Constituiçăo norte-(Imericana. Rio de Janeiro: Forense Universitária, 1986. p. 305). Conferir, ainda, a discussão sobre a legitimidade popular na regra da Democracia representativa sob o enfoque da Constituição dos EUA: GOLDWIN, Robert A., SCHAMBRA, William A. (orgs.). A Comıstituiçäo norte-(Imericana. Rio de Janeiro: Forense Universitária, 1986. p. 305; CERRI, Augusto. Corso di giustizia costituzionale. 2. ed. Milano: Giuffrè Editore, 1997. p. 17.

13. TROPER, Michel. Justice constitutionnelle et démocratie. Revue Française de Droit Constitutionnel. Paris: Presses Universitaires de France, 1990. p. 31; STARCK, Christian. La légitimité ... Op. cit. p. 73.

14. Como salientado por Konrad Hesse, "esse controle significa uma incorporação, até agora desconhecida à tradiçāo constitucional alemã, do Poder Judiciário no sistema de refreamentos de poderes e controles. O elemento estatal-juridico do equilíbrio de poderes, que se torna eficaz, nele, une-se como democrático, porque ele abre as possibilidades à minoria de recorrer à proteção do Tribunal Constitucional comtra um prejuizo, real ou presendido, de sua posição e, assim, de consolidar sua situaçāoo - em que, naturalmente, o Tribunal Constitucional nenhum outro peso pode lançar no prato da balança senão) aquele da sua própria autoridade" (Elementos de... Op. cit. p. 376).

15. MIRANDA, Jorge. Nos dez anos de funcionamento do tribunal constitucional. In: Vários autores. Legitimidade e legitimação da justiça constitucional. Coimbra: Coimbra, 1995. p. 95.

16. O posicionamento moderno diferencia-se da clássica posição do abade Emmanuel Sieyès (17481836), em sua obra Qu'est-ce que le tiers État? (O que é o Terceiro Estado), para quem o titular do poder constituinte era a nação. 
seus representantes eleitos, em Assembléia Nacional Constituinte, que efetivamente o exercem, pois a titularidade do Poder liga-se à idéia de soberania do Estado, uma vez que mediante o exercício do poder constituinte originário se estabelecerá sua organização fundamental pela Constituição, que é sempre superior aos poderes constituídos, de maneira que toda manifestação dos poderes constituídos somente alcança plena validade se se sujeitar à Carta Magna. ${ }^{17}$

Portanto, conforme os ensinamento de Goffredo Telles Junior, “o Poder do Congresso Nacional não é um Poder originário, nem autônomo, nem incondicionado. Ele não se rege por si mesmo, uma vez que sua atuação é pautada pelas normas da Constituição. Ele não leva em si a lei de seu próprio exercício. Não é um Poder soberano. O Poder Legislativo, considerando como Poder do Congresso Nacional, é um Poder constituído, um Poder exercido em conformidade com o que manda o Poder constituinte" 18

Assim, o Poder Constituinte originário estabelece a Constituição de um novo Estado, organizando-o e criando os poderes destinados a reger os interesses de uma comunidade. Tanto haverá Poder Constituinte no surgimento de uma primeira Constituição, quanto na elaboração de qualquer Constituição posterior. ${ }^{1 "}$

A idéia da existência de um Poder Constituinte é o suporte lógico de uma Constituição superior ao restante do ordenamento jurídico e que, em regra, não poderá scr modificada pelos poderes constituídos. É, pois, esse Poder Constituinte, distinto, anterior e fonte da autoridade dos poderes constituídos, com eles não se confundindo.

O Poder Constituinte caracteriza-se por ser inicial, ilimitado, autônomo e incondicionado. É inicial, pois sua obra - a Constituição - é a base da ordem jurídica;

17. CANOTILHO, J. J. Gomes. Direito... Op. cit. p. 102; MELlo FILHO, José Celso. Con.stituição Federal anotada. 2. ed. São Paulo: Saraiva, 1985. p. 14; SALDANHA, Nelson. SALDANHA, Nelson. $O$ Poder comstituinte. São Paulo: Revista dos Tribunais, 1986. p. 74; FERREIRA FILHO, Manoel Gonçalves. $O$ poder constituinte. 2. ed. São Paulo: Saraiva, 1985. p. 15; SANTOS, Aricê Moacir Amaral. SANTOS, Aricê Moacyr Amaral. O poder constituinte. São Paulo: Sugestões Literárias, 1980. p. 16. Nesse sentido decidiu a Suprema Corte Americana: "Diz-se às vezes que este tribunal arroga-se o poder de dominar ou controlar a ação dos representantes do povo. Isso é uma interpretação errônea. A Constituição é a suprema lei do país, ordenada e estabelecida pelo povo. Toda a legislação deve conformar-se aos princípios fixados por ela. Quando uma lei do Congresso é adequadamente contestada nos tribunais, por não se conformar ao mandamento constitucional, o ramo judiciário do Governo só tem um dever a cumprir: pôr o artigo da Constituição que é invocado ao lado da lei que é contestada e decidir se esta última está de acordo com aquele artigo" (United States v. Butler; 297 U.S. I, 62 (1936), apud SCHWARTZ, Bernard. Direito... Op. cit. p. 259).

18. TELLES JUNIOR, Goffredo. A Constituição, a Assembléia Constituinte e o Congresso Nacional. São Paulo: Saraiva, 1986. p. 51.

19. O poder constituinte poderá manifestar-se tanto por um movimento revolucionário quanto por urn movimento político (Assembléia Nacional Constituinte). 
é ilinitado e autônomo, pois não está de modo algum limitado pelo direito anterior, não tendo que respeitar os limites postos pelo direito positivo antecessor; e, finalmente, ć incondicionado, pois não está sujeito a qualquer forma prefixada para manifestar sua vontade; não tem ela que seguir qualquer procedimento determinado para realizar sua obra de constitucionalização. ${ }^{20}$

Dessa forma, a legitimidade formal do Tribunal Constitucional existe no momento da promulgação de uma Constituição que o instituiu formalmente, pois haverá a presunção de que sua criação foi decorrente da vontade soberana do Povo organizado em Assembléia Nacional Constituinte. ${ }^{21}$

Esse entendimento é corroborado por Bernard Schwartz, quando explica que "a teoria americana admite uma verdadeira hierarquia de legisladores dentro do Estado. No ápice encontra-se a Assembléia Constituinte, à qual só o povo delegou a autoridade de criar o instrumento orgânico que rege o Estado. Os dispositivos da Constituição aprovados por ela constituem a lei suprema do país. A lei elaborada por qualquer órgão do Estado só é válida desde que não entre em conflito com a Constituição" 22

Igualmente, esse é o exato sentido da lição de Thomas Cooley, ao analisar o sistema constitucional norte-americano, afirmando que "o Poder Judicicirio tendo de decidir qual a lei que deve ser aplicada em determinada controvérsia, pode encontrar a vontade do poder legislativo, conforme é expresso em lei, em conflito com a vontade do povo em conformidade do expresso na Constituição, e as duas se

20. Nesse sentido, Canotilho sintetiza essas caracteristicas dizendo que "o poder comstituinte, na teoria de Siejés, seria um poder inicial, antónomo e ommipotente. É inicial porque não existe, antes dele. nem de facto nem de direito, qualquer outro poder: $\dot{E}$ nele que se situa, por excelência, a vomade do soberamo (instância juridico-política dotada de autoridade suprema). É um poder autónomo: a ele e só a ele compete decidir se, como e quando, deve "dar-se'uma Constituigão à Nação. É um poder omnipotente. incondicionado: " poder constituinte não está subordinado a qualquer regra de forma ou de fundo" (Direito... Op. cit. p. 94).

21. Otto Bachof adverte que "não tem muito mais forģa a afirmação de que o poder judicial é antidemocrático. O juiz não é menos órgão do povo que todos os demais óngãos do Estado. A alusão da falta de imediatez de sua comissão pelo pơo não comstitui um argumento convincente perante of fato de que também o Governo, o Presidente, os funcionários.., contam somente com um mandato indireno do) povo; e mesmo o Parlamento nũo pole ser comsiderado como diretamente comissionado, sem que haja „um aspecto muito relativo, pois sua composifaño esta de fato muito mais ligada aos partidos políticos. Ademais, mais importante que a classe do mandano é a fung ão desempenhada. O juiz administra justiga em nome do povo - essa näo é uma fórmula vazia - da mesma forma que o Parlamento promulga leis e " Govermo governa em nome do poiso. (BACHOF, Oto. Jucees y constitución. Madri: Civitas, 1987. p. 59. Reimpressão)

22. SCHWARTZ, Bernard. Direito comstifucional americamo. Rio de Janeiro: Forense, 1966. p. 26. 
não poderem conciliar. Nesse caso, como o poder legislativo é o conferido pela Constituição, é claro que o poder delegado foi o que se excedeu; que o mandatário não se manteve dentro da órbita do mandato. O excesso, por conseguinte, é nulo e $e ́$ dever do tribunal reconhecer e fazer efetiva a Constituição como o direito primordial, e recusar-se a dar execução ao ato legislativo, e assim o anular na prática" 23

Materialmente, sendo instituído por Constituições formais, os Tribunais ou Cortes Constitucionais são órgãos de garantia da supremacia de seus princípios, objetivos e direitos fundamentais, resguardando, dessa forma, o Estado de Direito e preservando as idéias básicas da Constituição material.

Canotilho explica que "globalmente consideradas, as garantias de existência da Constituição consistem: (I) na vinculação de todos os poderes públicos (designadamente do legislativo, executivo e judicial) à Constituição; (2) na existência de competências de controlo, políticas e jurisdicionais, do cumprimento da Constituição" ${ }^{24}$

A jurisdição constitucional, portanto, tem como ponto fundamental a defesa dos valores constitucionais básicos, afirmados livremente pelo povo em Assembléia Nacional Constituinte, exercendo, por conseguinte, um controle negativo. Como salientado por Jorge Miranda, "o Tribunal Constitucional exerce um poder de controle negativo, um pouvoir d'empêcher, não um poder de impulsão, um poder positivo" 25

Os eventuais confrontos entre a legitimidade da Justiça constitucional e a legitimidade da maioria legiferante devem ser resolvidos em uma aplicação cquilibrada e harmônica do princípio da separação de funções estatais, pois todos os poderes exercem funções únicas do Estado, dentro de uma visão mais contemporânea das funções estatais, que reconhece assentar-se o Estado Constitucional de Direito na idćia de unidade, pois o poder soberano é uno, indivisível, existindo órgãos estatais, cujos agentes políticos têm a missão precípua de exercerem atos de soberania Aliás, bcm o disse Rousseau, o poder soberano é uno. Não pode sofrer divisão. Assim, o que a doutrina liberal clássica pretende chamar de separação de poderes, o

23. COOLEY, Thomas. Princípios gerais de direito comstitucional dos Estados Unidos da América do Norte. 2. ed. São Paulo: Revista dos Tribunais, 1982. p. 142.

24. CANOTILHO, J. J. Gomes. Direito ... Op. cit. p. 782.

25. MIRANDA, Jorge. Nos dez anos de funcionamento do tribunal constitucional. In: Vários autores. legirimidade e legitimaşão da justişa comstitucional. Coimbra: Coimbra, 1995. p. 95. 
constitucionalismo moderno determina divisão de tarefas estatais, de atividades entre distintos órgãos autônomos. ${ }^{26}$

As Constituições, visando, principalmente, evitar o arbítrio e o desrespeito aos direitos fundamentais do homem, prevêem a existência dos Poderes do Estado, independentes e harmônicos entre si, repartindo entre eles as funções estatais, bem como criando mecanismos de controles recíprocos, sempre como garantia da perpetuidade do Estado democrático de Direito.

A divisão segundo o critério funcional é a célebre "separação de Poderes" que consiste em distinguir três funções estatais, quais sejam, legislação, administração c jurisdição, que devem ser atribuídas a três órgãos autônomos entre si, que as exercerão com exclusividade, foi esboçada pela primeira vez por Aristótcles, na obra "Política" detalhada, posteriormente, por John Locke, no Segundo tratado do governo civil. E, finalmente, consagrada na obra de Montesquieu, $O$ espírito das leis, a quem devemos a divisão e distribuição clássicas, tornando-se princípio fundamental da organização política liberal e transformando-se em dogma pelo art. 16 da Declaração Francesa dos Direitos do Homem e do Cidadão, de 1789 , e é prevista no art. $2^{\circ}$ da nossa Constituição Federal. ${ }^{27}$

Como salientam Canotilho e Moreira, "um sistema de governo composto por uma pluralidade de órgãos requer necessariamente que o relacionamento entre os vários centros do poder seja pautado por normas de lealdade constitucional (Verfassungstreue, na terminologia alemã). A lealdade institucional compreende duas vertentes, uma positiva, outra negativa. A primeira consiste em que os diversos órgãos do poder devem cooperar na medida necessária para realizar os objetivos constitucionais e para permitir o funcionamento do sistema com o mínimo de atritos possíveis. A segunda determina que os titulares dos órgãos do poder devem respeitar-se mutuamente e renunciar a prática de guerrilha institucional, de abuso de poder, de retaliação gratuita ou de desconsideração grosseira. Na verdade, nenhuma cooperação constitucional será possível, sem ıma deontologia política, fundada no respeito das pessoas e das instituições e mum apurado sentido da responsabilidade de Estado (statesmanship)". ${ }^{2 \times}$

26. CLÈVE, Clémerson Merlin. Atividade legislativa do Poder Executivo no estado comemporâneo e na Constituiçăo de 1988. São Paulo: Revista dos Tribunais, 1993. p. 26.

27. Nuno Piçarra faz detalhado estudo sobre a falência da idćia de tripartição rígida de poderes e sua substituição por uma teoria geral das funções estatais (A separação dos poderes como doutrina e princípio) constitucional. Coimbra: Coimbra, 1989. p. 264).

28. CANOTILHO, J. J. Gomes, MOREIRA, Vital. Os poderes do presidente da República. Coimbra: Coimbra, 1991.p. 71. 
Lembremo-nos que o objetivo inicial da clássica separação das funções do Estado e distribuição entre órgãos autônomos e independentes tinha como finalidade a protcção da liberdade individual contra o arbítrio de um governante onipotente. $O$ Dircito Constitucional contemporâneo, apesar de permanecer na tradicional linha da idéia de Tripartição de Poderes, já entende que esta fórmula, se interpretada com rigidez, tornou-se inadequada para um Estado que assumiu a missão de fornecer a todo o seu povo o bem-estar, devendo, pois, separar as funções estatais, dentro de um mecanismo de controles recíprocos, denominado "freios e contrapesos" (checks and balances).

Como salientado pelo Chief Justice Marshall, no célebre caso Marbury v. Madison, "para que então limitarem-se os poderes, e para que estabelecer-se tal limitação em um documento escrito, se tais limites puderem, a qualquer momento, ser ultrapassados por aqueles a quem se pretende restringir" ${ }^{29}$

Assim, as funções estatais de soberania são modernamente atribuídas a vários órgãos estatais, entre eles, aos Tribunais ou Cortes Constitucionais, que, entre várias outras importantes funções, deve zelar pelo equilíbrio entre os Poderes, liscalizando-os, e pelo respeito aos direitos fundamentais. ${ }^{30}$

Como salienta Cappelletti, "efetivamente, resulta difícil imaginar que atualmente poder-se-ia assegurar um sistema qualquer de equilibrio eficaz entre os poderes sem o crescimento e diversificação do próprio ramo judiciário" 31

A esses órgãos, a Constituição Federal confiou parcela da autoridade soberana do Estado, garantindo-lhes autonomia c independência.

Não existirá, pois, um Estado democrático de direito, sem que hajam Poderes de Estado, independentes e harmônicos entre si, bem como previsão de direitos lundamentais e instrumentos que possibilitem a liscalização, a perpetuidade e a cfetividade desses requisitos. ${ }^{32}$ Todos esses temas são de tal modo ligados que a

29. Marbury v. Madisom, U.S. Supreme Court, 177 (1803). Cf. a íntegra da decisão: SWISHER, Carl Brent. Decisões históricas da Corte Suprema. Rio de Janeiro: Forense, 1962. p. 9- 14; RODRIGUES, Lêda Boechat. A Corte Suprema e direito comstitucional americano. Rio de Janeiro: Forense, 1958. p. 36 ss.

30. BANDRÉS, José Manuel. Poder judicial y constitución. Barcelona: Casa Editorial, 1987. p.

31. CAPPELLETTI, Mauro. Necesidad y legitimidad de la justicia constitucional. In: Vários autores. ribunales constituciomales europeus y derechos fundamentales. Madri: Centro de Estudios Constitucionales, 1984. p. 612.

32. A necessidade de existência de um órgão imparcial de controle e efetividade da Constituição é reforçada pela observação trazida por Vieira de Andrade: "Outras vezes, o legislador goza do poder de restringir os direitos, liberdades e garantias, um poder que a Constituição prevê até em termos genéricos. embora com a garantia da necessidade, adequaşão e proporcionalidade das restrigöes, designadamente da sua necessidade para defesa de um valor constitucionalmente protegido e do respeito pelo contéudo essencial do preceito" (ANDRADE, J. C. Vieira de. Legitimidade da justiça constitucional e princípio da maioria. In: Vários autores. Legitimidade e legitimą̧ano da justişa constitucional. Coimbra: Coimbra, 1995. p. 81). 
derrocada de um, fatalmente, acarretará a supressão dos demais, com o retorno do arbítrio e da ditadura.

Dessa necessidade protetiva do Estado de Direito advém a legitimidade material da justiça constitucional, pois como afirmado por Jorge Miranda, "para lá da legitimidade adveniente da previsão em Constituição democrática, há uma legitimidade própria dos órgãos de controlo, inerente ao princípio da divisão e limitação de poder do Estado de direito democrático" 33

Assim, o fundamento básico da legitimidade material da Justiça constitucional está na necessidade de consagração e efetivação de um rol de princípios constitucionais básicos e direitos fundamentais tendentes a limitar e controlar os abusos de poder do próprio Estado e de suas autoridades constituídas e a consagração dos princípios básicos da igualdade e da legalidade como regentes do Estado moderno e contemporâneo, ${ }^{34}$ pois nos Estados onde o respeito à efetividade dos direitos humanos fundamentais não for prioridade, a verdadeira Democracia inexiste, ${ }^{35}$ como ensina Norberto Bobbio ao afirmar que sem respeito às liberdades civis, a participação do povo no poder político é um engano, e sem essa participação popular no poder estatal, as liberdades civis têm poucas probabilidades de durar. ${ }^{36}$

Importantíssima a observação feita por Rivero, após constatar a crise na Democracia representativa - analisada no capítulo anterior - de que " a velha idéia que dominou todo o liberal século XIX, da proteção da liberdade pela lei, tende a ser substituida pela idéia experimental da necessidade da proteção das liberdades contra a lei. E essa evolução tem sido possível graças a esse fenômeno extraordinário que é a existência de uma autoridade superior ao legislador, de uma autoridade encarregada de impor o legislador o respeito à Constituição" 37

\section{MIRANDA, Jorge. Nos dez anos... Op. cit. p. 98.}

34. Como salienta François Luchaire, a idéia básica da criação do Conselho Constitucional foi garantir o respeito às normas constitucionais e a efetividade dos direitos fundamentais por ela proclamados (LUCHAIRE, François. Le conseil constitutionnel. Paris: Economica, 1980. p. 19). No mesmo sentido: BON, Pierre. La légitimité du conseil Constitucionnel français. In: Vários autores. Legitimidade e legitimação da justiça constitucional. Coimbra: Coimbra, 1995. p. 143.

35. Interessante observação é feita por Javier Perez Royo, ao afirmar que "nos países com uma tradição democrática ininterrupta, ou melhor dizendo, com uma tradição constitucional ininterrupta, que não necessitaram destruir temporariamente o Estado Constitucional, na passagem do Estado Liberal ao Estado Democrático, nāo se criou (Inglaterra) ou houve resistência ì introdução de um controle de constitucionulidade das leis (Suiça)" (Tribunal constituciomal y division de poderes. Madri: Tecnos, 1988. p. 24).

36. ВОВВIO, Norberto. Igualdade y libertad. Barcelona: Paidós, 1993. p. 117.

37. RJVERO, Jean. A modo de sintesis. In: Vários autores. Tribunales constitucionales europeus y derechos fundamentales. Madri: Centro de Estudios Constitucionales, 1984. p. 666. 
Ora, a questão essencial sobre a legitimidade da Justiça constitucional exige uma interpretação que compatibilize a representação popular, enquanto direito da maioria, e a defesa dos princípios constitucionais e direitos fundamentais, devendo pautar-se pela indagação sobre as tarefas e os objetivos básicos de uma Constituição Federal, que entre outros, podem ser destacados o de Justiça, eqüidade, equilíbrio de interesses, resultados satisfatórios, razoabilidade, praticabilidade e segurança jurídica. ${ }^{3 \mathrm{x}}$

Há, portanto, necessidade de direcionarem-se todas as regras hermenêuticas para garantir-se a plena aplicabilidade e efetividade dos direitos humanos fundamentais perante o governo da maioria, inclusive compatibilizando-se as lições de Ferdinand Lassalle e Konrad Hesse, no sentido de que uma Constituição tem caráter informador de todo o ordenamento jurídico, e se em seu gênese a Constituição de um país é "a soma dos fatores reais do poder que regem uma nação" ${ }^{39}$ após a sua edição, "graças ao elemento normativo, ela ordena e conforma a realidade política e social" 40

Portanto, as previsões constitucionais, e em especial os direitos humanos fundamentais e os princípios fundamentais da República, não são meros enunciados teóricos desprovidos de coercibilidade jurídica. Muito pelo contrário, uma Constituição possui supremacia incondicional em relação a todo ordenamento jurídico e força normativa inquestionável, devendo suas previsões servir de princípios informadores obrigatórios na atuação do poder público, no âmbito de todos os Poderes de Estado.

Somente com o pleno respeito aos princípios e objetivos básicos da Constituição e aos Direitos Fundamentais poderemos almejar a conquista da verdadeira liberdade, projeto maior de um Estado Democrático de Direito, no exato sentido que lhe empresta a definição de Roscoe Pound, para quem liberdade consiste "na reserva, para o indivíduo, de certas expectativas fundamentais razoáveis que entendem com a vida na sociedade civilizada e liberação em relação ao exercício arbitrário e desarrazoado do poder e da autoridade por parte daqueles que são nomeados ou escolhidos em sociedade politicamente organizada com o objetivo de ajustar relações e ordenar a conduta e se tornam, dessa maneira, capazes de aplicar a força dessa sociedade aos indivíduos" 41

38. HÄBERLE, Peter. Hermenêutica constitucional. Porto Alegre: Sérgio Fabris, 1997. p. 11.

39. LASSALLE, Ferdinand. A essência da Constituição (Uber das Verfassungswesen). 3. ed. Rio de Janeiro: Liber Juris, 1995. p. 37.

40. HESSE, Konrad. A força normativa... Op. cit. p. 24.

41. POUND, Roscoe. Liberdades e garantias constitucionais. 2. ed. São Paulo: Ibrasa, 1976. p. 5 
Cappelletti corrobora esse entendimento afirmando que "somente nos sistemas democráticos de governo existe uma oportunidade para que se respeite os direitos fundamentais", de maneira que "a Democracia não pode sobreviver em um sistema em que os direitos e garantias fundamentais carę̧am de uma proteção eficaz. Como muito acertadamente se tem observado, a preservação das liberdades públicas exige a eliminação da concentração de poder e a distribuição de todo o poder que não possa ser eliminado - um sistema de equilíbrio de poderes"; e conclui: "uma Justiça razoavelmente independente dos caprichos e intolerâncias das maiorias pode contribuir em grande medida para a Democracia" ${ }^{42}$

Sem respeito a essas regras não haverá Estado de Direito, desaparecendo a liberdade e conseqüentemente a participação popular nos negócios políticos do Estado, quebrando-se o respeito ao princípio da soberania popular, que proclama todo o poder emanar do povo, com a consequiência nefasta do fim da Democracia. ${ }^{43}$

Bernard Schwartz conclui nesse sentido, afirmando que "o ponto básico na concepção americana do princípio da legalidade é o respeito aos princípios que estão acima do Estado e que são confirmados pelos tribunais. No sistema americano, tais princípios são os estabelecidos pela Constituição federal. Os atos legislativos que entrarem em conflito com eles serão declarados nulos pelos tribunais americanos. Deve-se admitir, afirmou a Corte Suprema dos Estados Unidos, que em todo Governo livre há certos direitos que estão acima da competência do Estado. O Governo que não reconhece tais direitos, que mantém a vida, a liberdade, a prosperidade de seus cidadãos sujeitas, a qualquer momento, à disposição absoluta e ao domínio ilimitado mesmo do mais democrático depositário do poder, é afinal de contas apenas um despotismo. É verdade que é um despotismo de muitos da maioria, se quisermos chamá-lo assim -, mas não deixa de ser um despotismo" ${ }^{44}$

A legitimidade da Justiça constitucional consubstancia-se, portanto, na necessidade de exigir-se que poder público, em todas as suas áreas, seja na distribuição da Justiça, seja na atuação do Parlamento ou na gerência da res pública, paute-se pelo respeito aos princípios, objetivos e direitos fundamentais consagrados em um texto constitucional, sob pena de flagrante inconstitucionalidade de suas condutas e perda

42. CAPPELLETTI, Mauro. Necesidad... Op. cit. p. 633.

43. Cappelletti corrobora esse posicionamento ao afirmar que não crê existir a menor oportunidade para a sobrevivência da liberdade se não se mantiverem sistemas bem equilibrados de controles recíprocos e concluindo que "o crescimento do poder judicial constitui, naturalmente, um instrumento necessário para a realizą̧ão desse equilibrio" (Necesidad... Op. cit. p. 612).

44. SCHWARTZ, Bernard. Direito... Op. cit. p.43. 
da própria legitimidade popular de seus cargos e mandatos políticos pelo ferimento ao Estado de Direito.

3. Composição dos Tribunais Constitucionais.

Igualmente, apresenta-se como fator legitimador da Justiça constitucional a participação popular, por intermédio de seus representantes eleitos no Parlamento e no Executivo, na escolha dos membros dos Tribunais ou Cortes Constitucionais.

Assim, a questão da composição das Justiças constitucionais é certamente a que provoca as mais equivocadas interpretações e os mais árduos debates, situandose em dois níveis: político e jurídico.

Como salienta Pedro Cruz Villalón, a questão da legitimidade dos Tribunais Constitucionais deve ser analisada em sua origem, ou seja, se a sua forma de composição é ou-não respaldada pela idéia de soberania popular. ${ }^{45}$

O tratamento diferenciado dado à investidura dos juízes da jurisdição constitucional é explicado em virtude de sua natureza dúplice, e porque suas decisões envolvem a supremacia constitucional, os atos das mais elevadas autoridades do Estado e, principalmente, as leis do Parlamento, que são consideradas como expressão da vontade geral.

Em razão disso, essa jurisdição não pode ter a mesma composição das jurisdições ordinárias, sob pena de contestação de sua legitimidade, e deve apresentar os três requisitos de observância obrigatória na composição política da Justiça constitucional para que reforcem sua legitimidade: pluralismo, representatividade e complementaridade.

Em relação ao pluralismo, o importante é que o órgão encarregado da Justiça constitucional tenha uma composição pluralista, de maneira que possa aumentar a representatividade global do sistema, protegendo os grupos minoritários que não tenham acesso aos ramos políticos.

Observe-se que, para garantia da atualização do pluralismo e da representatividade, em regra, deverá haver uma renovação regular dos membros do Tribunal ou Corte, que devem ter mandatos certos e não muito longos, de maneira que nem a designação da maioria coincida com o início do mandato do Chefe de Governo, nem que se perpetuem no cargo, impedindo, assim, que eventuais evoluções políticas

45. VILLALÓN, Pedro Cruz. Legitimidade da justiça constitucional e princípio da maioria. In: Vários autores. Legitimidade e legitimą̧ão da justiça constitucional. Coimbra: Coimbra, 1995. p. 87. 
e sociais, com reflexos imediatos na composição do Parlamento e na eleição do Chefe do Executivo, não sejam acompanhadas pela Justiça constitucional. Dessa forma, o ritmo de alterações, por meio de novas nomeações envolvendo os outros dois ramos do Governo (Legislativo e Executivo), permitirá assegurar que a evolução social da Corte, que não se mostrará alheia às novas exigência decorrentes da constante mutação da sociedade. ${ }^{46}$

A representatividade consiste na participação da maioria qualificada do Parlamento para a aprovação do nome do juiz constitucional e parece garantir um maior pluralismo, como reflexo do próprio pluralismo democrático das Câmaras Legislativas, pois acaba por permitir às minorias parlamentares o direito de veto ao nome indicado para compor a Corte Constitucional, uma vez que essa deve representar necessariamente as várias tendências e partes da sociedade, inclusive as diversas minorias. ${ }^{47}$

Por fim, a complementaridade consubstancia-se na necessidade de multiplicidade e variação de experiências profissionais anteriores dos juízes constitucionais, pois, na realidade, a experiência de um juiz constitucional proveniente da magistratura de carreira é diversa daquele proveniente da advocacia ou do Ministério Público, ou ainda, da Universidade Pública, ou do próprio Parlamento, ou outros ramos profissionais. Essa complementação de experiências acaba por legitimar a Justiça constitucional, afastando-a tanto do tecnicismo exacerbado, quanto da política exagerada.

Concordamos, portanto, com Favoreu quando aponta que o modo de designação dos juízes constitucionais pelas autoridades políticas pelos diversos sistemas jurídicos constitui, além de uma tradição da Justiça constitucional, uma necessidade de legitimidade, que repousa em grande parte nessa técnica de designação. ${ }^{48}$

46 CAPPELLETTI, Mauro. Tribunales... Op. cit. p. 625.

47 Essa necessidade de pluralisıno e representação das minorias não passou despercebida pelo então Ministro do STF, Francisco Rezek, que afirmou que "para reconforto dos brasileiros, seu tribunal mais alto não é e não será jamais uma confraria de almas-irmãs. Não o tem sido, tampouco, a Suprema Corte Aınericana; e isto, dado o pluralismo que caracteriza as duas sociedades - e que, no Brasil, não se limita ao plano das idéias - , é mais que positivo. Chega a ser imperioso, na medida em que o poder político facultado às duas casas de justiça reclama que representem, de modo autêntico e completo, um quadro social heterogêneo e marcado por constante transformação" (prefácio da obra de BAUM, Lawrence. A Suprema... Op. cit. p. 8).

48. FAVOREU, Louis. La légitimité de la justice constitutionnelle et la composition des juridictions constitutionnelles. Legitimidade e legitimaçāo da justiça constitucional. Coimbra: Coimbra, 1995. p. 233. 
4. Fundamentação e Aceitação Popular das Decisões dos Tribunais Constitucionais.

Outro grande pilar que sustenta a legitimidade da Justiça constitucional é a aceitação de suas decisões pelos demais poderes por ela fiscalizados e, principalmente, pela opinião pública, motivo pelo qual todos os seus pronunciamentos devem ser fundamentados e públicos.

Assim, a verdadeira, duradoura e incontrastável legitimidade da Justiça constitucional será concedida pela opinião pública, pois somente ela é que, em definitivo, consagrará ou rejeitará essa instituição, analisando-a em virtude de sua jurisprudência e de sua atuação perante o Estado, pois, como ressalta Henry Abraham, "as decisões que contrariam o consenso geral simplesmente acabam não perdurando" 4"

Como salienta Antonio Scarance Fernandes, a grande destinatária da motivação das decisões judiciais é a comunidade, no intuito de ter "condições de verificar se juiz e por conseqüência a própria Justiça, decide com imparcialidade e com conhecimento da causa. É através da motivação que se avalia o exercício da função jurisdicional". ${ }^{50}$

Historicamente, isso é facilmente constatado ao se comparar o desenvolvimento da Justiça constitucional dos EUA e da França.

Em relação ao Conselho Constitucional francês, constata-se que sua legitimidade foi fortemente contestada, principalmente por razões históricas e ideológicas contrárias à magistratura em geral. Como salienta a doutrina francesa, o controle de constitucionalidade das leis sempre foi ausente no Direito francês, havendo mesmo, uma hostilidade à aplicação dessa técnica. No entanto, com a melhora da instituição e evolução de sua jurisprudência, houve considerável mudança da visão francesa sobre o controle jurisdicional de constitucionalidade, principalmente quando o Conselho Constitucional ampliou seu papel e passou a exercer mais efetivamente um controle geral da constitucionalidade das leis com ênfase, basicamente, na proteção dos direitos fundamentais. ${ }^{51}$

49. ABRAHAM, Henry. A Corte Suprema no evolutivo processo político. In: Vários autores. Ensciios sobre a Constituição dos Estıdos Unidos. Rio de Janeiro: Forense Universitária, 1978. p. 99.

50. FERNANDES, Antonio Scarance. Processo penal constitucional. São Paulo: Revista dos Tribunais, 1999. p. 117.

51. BON, Pierre. La légitimité... Op. cit. p. 140; TROPER, Michel. Justice constitutionnelle et démocratie. Revue Française de Droit Constitutionnel. Paris. Presses Universitaires de France, 1990. p. 31. Pierre Bon, inclusive, salienta que atualmente a legitimidade do Conselho Constitucional é largamente adınitida, indicando como exemplo o colóquio organizado pela Assembléia Nacional e pela Associação francesa dos constitucionalistas em 13 de março de 1987, sob o teına "O Conselho Constitucional e os 
Diferentemente, desde 1803 (Madison v. Marbury), a Corte Suprema americana iniciou a aquisição de reconhecimento e aceitação popular, ganhando grande respeito não-só perante os demais Poderes de Estado, mas perante o próprio povo, que passou a enxergá-la como o último bastião na defesa dos Direitos Fundamentais.

Como lembra Bernard Schwartz, "não é a Corte Suprema sozinha, mas a Corte Suprema, apoiada pela força da opinião pública informada, que tem tornado o controle judicial da constitucionalidade um fator tão importante no funcionamento do sistema de Governo americano" uma vez que "a aceitação da Corte Suprema e de sua autoridade na esfera constitucional está atualmente tão arraigada na consciência americana quanto a aceitação da competência dos tribunais em questões de Direito Privado na Inglaterra", para concluir que "o apoio básico do Judiciário federal dos Estados Unidos não se encontra na sua posição constitucional, que, em vários aspectos, é inerentemente fraca em comparação com a do Legislativo e a do Executivo, mas na aceitação pela opinião pública do seu papel conı guardião da Constituição americana. Num Governo democrático, representativo cono o nosso, escreve um juiz americano, o poder do Judiciário depende grandemente de sua reputação quanto à sua independência, integridade e bom senso" 52

Para garantir apoio a seus julgados e, conseqüentemente, reafirmação de sua legitimidade, historicamente o estilo das decisões da diversas Cortes Constitucionais foi alterado, visando um maior detalhamento de sua motivação e propiciando maior acesso popular aos elementos básicos de sua fundamentação, por meio de publicidade de seus acórdãos..$^{53}$

Como ressalta René David, ao analisar o desenvolvimento no estilo formal das decisões, "um outro elemento a considerar é o estilo das decisões judiciárias. Estas, atualmente, devem ser sempre motivadas. A obrigação de motivar os julgamento $e ́$, no entanto, recente. Durante muito tempo, concordou-se em ver nos julgamentos um

partidos políticos", onde a maioria dos parlamentares afirmou sua adesão ao princípio do controle de constitucionalidade das leis a ser exercido pelo Conselho Constitucional, concluindo que a Justiça Constitucional da França adquiriu legitimidade e encontra-se no mesmo stutus que as demais Cortes Constitucionais européias, em defesa do Estado de Direito da França.

52. SCHWARTZ, Bernard. Direito... Op. cit. pp. 184- 186.

53. Em relação a publicidade dos atos processuais, Antonio Scarance Fernandes afirma que "tratase de garantia relevante e que assegura a transparência da atividade jurisdicional, permitindo ser fiscalizada pelas partes e pela própria commidade. Com ela são evitados excessos ou arbitrariedades no desenrylar da causa, surgindo, por isso, a garantia como reaçäo aos processos secretos, proporcionando aos cidadãos a oportunidade de fiscalizar a distribuição da Justiça" (Processo penal constitucional. São Paulo: Revista dos Tribunais, 1999. p. 63). 
exercício de autoridade, que não tinha de ser justificado. A prática de motivar os julgamentos estabeleceu-se gradualmente na Itália a partir do século XVI e na Alemanha no século XVIII; contudo, só em 1790 na França e em 1879 na Alemanha foi imposta aos juizes uma obrigação geral de motivar as decisões. O princípio de que os julgamentos devem ser motivados está hoje firmemente estabelecido; a própria Constituição o consagra na Itália. Surge aos olhos dos homens do nosso tempo una garantia contra as decisões arbitrárias e, mais ainda, talvez como uma garantia de que as decisões serão maduramente refletidas e conformes ao direito. As decisões judiciárias nos países da família romano-gernânica assemelham-se pelo fato de terem de ser todas motivadas". ${ }^{4}$

Importante não nos esquecermos da lição de Rui Barbosa, ao advertir que "a autoridade da Justiça é moral, e sustenta-se pela moralidade das suas decisões. $O$ poder não a enfraquece, desatendendo- $a$; enfraquece-a, dobrando-a. A majestade dos tribunais assenta na estima pública; e esta é tanto maior, quanto mais atrevida for a insolência oficial, que lhes desobedecer, e mais adamantina a inflexibilidade deles perante ela" $\$ 5$

São Paulo, março de 2003.

54. DAVID, René. Os grındes.... Op. cit. p. 125. Conferir, ainda, em relação à necessidade de motivação das decisōes judiciais: TUCCI, José Rogério Cruz e. A motivą̧ão da sentença no processo civil. São Paulo: Saraiva, 1987 e MOREIRA, José Carlos Barbosa. A motivação das decisões judiciais como garantia inerente ao Estado de Direito. Revista Brasileira de Direito Processual. v. I6. p. III.

55. BARBOSA, Rui. Obras completas de Rui Barbosa. Rio de Janeiro: Secretaria da Cultura Fundação Casa de Rui Barbosa, 1991. v. XIX, p. 300. 
5. Bibliografia.

ABRAHAM, Henry. A Corte Suprema no evolutivo processo político. In: Vários autores. Ensaios sobre a Constituição dos Estados Unidos. Rio de Janeiro: Forense Universitária, 1978.

ANDRADE, J. C. Vieira de. Legitimidade da justiça constitucional e princípio da maioria. In: Vários autores. Legitimidade e legitimação da justiça constitucional. Coimbra: Coimbra, 1995.

BACHOF, Otto. Jueces y constitución. Madri: Civitas, 1987. Reimpressão.

BANDRÉS, José Manuel. Poder judicial y constitución. Barcelona: Casa Editorial, 1987.

BARBOSA, Rui. Obras completas de Rui Barbosa. Rio de Janeiro: Secretaria da Cultura - Fundação Casa de Rui Barbosa, 1991. v. XIX, p. 300.

BAUM, Lawrence. A Suprema Corte Americana. Rio de Janeiro: Forense Universitária, 1987.

BERNS, Walter. A Constituição assegura esses direitos? In: Vários autores. $A$ Constituição norte-americana. Rio de Janeiro: Forense Universitária, 1986.

BESSETTE, Joseph M. Democracia deliberativa: o princípio da maioria no governo republicano. In: Vários autores. A Constituição norte-americana. Rio de Janeiro: Forense Universitária, 1986.

BOBBIO, Norberto. Igualdade y libertad. Barcelona: Paidós, 1993.

BON, Pierre. La légitimité du conseil Constitucionnel français. In: Vários autores. Legitinidade e legitimação da justiça constitucional. Coimbra: Coimbra, 1995.

BRITO, José de Sousa. Jurisdição constitucional e princípio democrático. In: Vários autores. Legitimidade e legitimação da justiça constitucional. Coimbra: Coimbra, 1995.

CANOTILHO, J .J. Gomes, MOREIRA, Vital. Os poderes do presidente da República. Coimbra: Coimbra, 1991.

CANOTILHO, J. J. Gomes. Direito... Op. cit. p. 102;

Jurisdição constitucional e intranquilidade discursiva. Perspectivas constitucionais nos 20 anos da Constituição de 1976. Coimbra: Coirnbra, 1996. v.1.

CAPPELLETTI, Mauro. Necesidad y legitimidad de la justicia constitucional. In: Vários autores. Tribunales constitucionales europeus y derechos fundamentales. Madri: Centro de Estudios Constitucionales, 1984.

CERRI, Augusto. Corso di giustizia costituzionale. 2. ed. Milano: Giuffrè Editore, 1997. 
CLÈVE, Clémerson Merlin. Atividade legislativa do Poder Executivo no estado contemporâneo e na Constituição de 1988. São Paulo: Revista dos Tribunais, 1993.

COOLEY, Thomas. Princípios gerais de direito constitucional dos Estados Unidos da América do Norte. 2. ed. São Paulo: Revista dos Tribunais, 1982.

DAVID, René. Os grandes sistemas do direito contemporâneo. São Paulo: Martins Fontes, 1998.

FAVOREU, Louis. Informe general introductorio. In: Vários autores. Tribunales Constitucionales europeus y derechos fundamentales. Madri: Centro de Estudios Constitucionales, 1984. p. 22; CANOTILHO, J. J. Gomes. Direito constitucional e teoria da Constituição. 2. ed. Coimbra: Almedina, 1998.

La légitimité de la justice constitutionnelle et la composition des juridictions constitutionnelles. Legitimidade e legitimação da justiça constitucional. Coimbra: Coimbra, 1995.

FERNANDES, Antonio Scarance. Processo penal constitucional. São Paulo: Revista dos Tribunais, 1999.

FERREIRA FILHO, Manoel Gonçalves. O poder constituinte. 2. ed. São Paulo: Saraiva, 1985.

GOLDWIN, Robert A., SCHAMBRA, William A. (orgs.). A Constituição norteamericana. Rio de Janeiro: Forense Universitária, 1986.

HÄBERLE, Peter. Hermenêutica constitucional. Porto Alegre: Sérgio Fabris, 1997.

HESSE, Konrad. Elementos de direito constitucional da República Federal da Alemanha. Porto Alegre: Sérgio Fabris, 1998.

LASSALLE, Ferdinand. A essência da Constituição (Uber das Verfassungswesen). 3. ed. Rio de Janeiro: Liber Juris, 1995.

LUCHAIRE, François. Le conseil constitutionnel. Paris: Economica, 1980.

MELLO FILHO, José Celso. Constituição Federal anotada. 2. ed. São Paulo: Saraiva, 1985.

MIRANDA, Jorge. Nos dez anos de funcionamento do tribunal constitucional. In: Vários autores. Legitimidade e legitimação da justiça constitucional. Coimbra: Coimbra, 1995.

Nos dez anos de funcionamento do tribunal constitucional. In: Vários autores. Legitimidade e legitimação da justiça constitucional. Coimbra: Coimbra, 1995. MOREIRA, José Carlos Barbosa. A motivação das decisões judiciais como garantia inerente ao Estado de Direito. Revista Brasileira de Direito Processual. v. 16. 
PIÇARRA, Nuno. A separação dos poderes como doutrina e princípio constitucional. Coimbra: Coimbra, 1989.

POUND, Roscoe. Liberdades e garantias constitucionais. 2. ed. São Paulo: Ibrasa, 1976.

QUEIROZ, Cristina M. M. Os actos políticos no estado de direito. Coimbra: Almedina, 1990.

REYES, Manuel Aragón. El juez ordinario entre legalidade y constitucionalidad. Bogotá: Instituto de Estudios Constitucionales, 1997.

RIVERO, Jean. A modo de sintesis. In: Vários autores. Tribunales constitucionales europeus y derechos fundamentales. Madri: Centro de Estudios Constitucionales, 1984.

RODRIGUES, Lêda Boechat. A Corte Suprema e o direito constitucional americano. Rio de Janeiro: Forense, 1958.

ROYO, Javier Perez Royo, Tribunal constitucional y division de poderes. Madri: Tecnos, 1988.

SALDANHA, Nelson. O Poder constituinte. São Paulo: Revista dos Tribunais, 1986.

SANTOS, Aricê Moacir Amaral. SANTOS, Aricê Moacyr Amaral. O poder constituinte. São Paulo: Sugestões Literárias, 1980.

SCHWARTZ, Bernard. Direito constitucional americano. Rio de Janeiro: Forense, 1966.

STARCK, Christian. La légitimité de la justice constitutionnelle et le principe democratique de majorite. In: Vários autores. Legitimidade e legitimação da justiça constitucional. Coimbra: Coimbra, 1995.

SWISHER, Carl Brent. Decisões históricas da Corte Suprema. Rio de Janeiro: Forense, 1962.

TELLES JUNIOR, Goffredo. A Constituição, a Assembléia Constituinte e o Congresso Nacional. São Paulo: Saraiva, 1986.

TROPER, Michel. Justice constitutionnelle et démocratie. Revue Française de Droit Constitutionnel. Paris: Presses Universitaires de France, 1990.

TUCCI, José Rogério Cruz e. A motivação da sentença no processo civil. São Paulo: Saraiva, 1987.

VILLALÓN, Pedro Cruz. Legitimidade da justiça constitucional e princípio da maioria. In: Vários autores. Legitimidade e legitimação da justiça constitucional. Coimbra: Coimbra, 1995. 